\title{
土浦亀城の戦前の独立住宅にみる外観と起居様式の特徵について THE EXTERIOR AND DWELLING STYLE OF HOUSES DESIGNED BY TSUCHIURA KAMEKI BEFORE WWII
}

\author{
田中厚子 \\ Atsuko TANAKA
}

\begin{abstract}
This article discusses Tsuchiura Kameki's use of International Style and traditional dwelling style elements in his prewar houses. Of the 56 houses he designed in the prewar period, 32 have International Style exteriors, 3 are Japanese style, and 11 incorporate elements of both. 11 of the houses' interiors are designed for chairs and tables, 5 for tatami, and 37 for both Japanese and Western-style living. Only 9 of the houses use the "International Style exteriors and chair-style living arrangements" Tsuchiura preferred, and 21 of them mix chairs and tatami mats behind an International Style facade. This demonstrates the difficulty of insisting on International Style exteriors and chair-style living arrangements. In reality, most of Tsuchiura's houses had individual Japanese-style rooms, but these were designed to be unrecognizable from the exterior.
\end{abstract}

Keywords: Kameki Tsuchiura, Residence, International style, Dwelling style, Residential Improvement,Japanese room 土浦亀城 住宅 国際様式 起居様式 住宅改善 和室

\section{1 . はじめに}

自邸をはじめとする土浦亀城の戦前の住宅は、「白い都市型モダ ニズム」として高く評価されている11。また、戦前の建築雑誌『国 際建築』に揭載された住宅をまとめた『現代住宅 1933-1940』 ${ }^{2)} に$ は、土浦の作品が、日本の建築家では最多の 15 件揭載されており、 戦前期のモダニズム住宅の先導的な役割を果たしたことがわかる。 しかしフランク・ロイド・ライトに関連した視点、およびモダニズ ムの視点以外から、住宅作品が論じられることはなかった ${ }^{3)}$ 。2001 年から 2002 年にかけて、士浦亀城建築事務所の建築に関する資料 (建築図面、設計資料、建築写真) が、東京都江戸東京博物館に寄 贈された ${ }^{4)}$ 。それらの資料から住宅作品を俯瞰すると、和風や、和 風と国際様式の中間的な外観をもつ住宅が存在しており、また平面 計画においては、和室をもつ事例が多く存在した。本稿では戦前の 住宅作品をとりあげ、その外観と起居様式から、「国際性」と「伝統 的起居様式」の振幅において、土浦が住宅において目指したものを 考察する。日本の住宅は、伝統的住宅の西欧化であるとともに、日 本に導入された西洋館の和風化であるという考え方 ${ }^{5}$ に基づけば、 土浦の住宅作品は、「外観と生活様式の両面において国際様式(椅子 坐式）の住宅」が、日本の現実のなかで、その伝統性との接点を見 出す過程と考えられる。戦前期の住宅一般について起居様式を論心゙

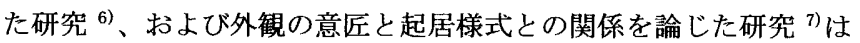
存在するが、土浦の住宅作品に触れたものはない。また、土浦亀城 の戦前の設計活動に関連した研究として、平面計画や事績に関する ものはあるが ${ }^{8)}$ 、外観の意匠と起居様式を論じたものはない。なお、
本稿は拙稿9)「土浦刍城の戦前の住宅に関する考察－国際様式と和室 について」を再検討し発展させたものである。

\section{2.土浦亀城の略歴}

土浦亀城は 1897 年 6 月 29 日、父市松 ${ }^{10}$ 、 、母光枝の長男として、 茨城県水戸市に生まれた。英語教師である父が、宣教師と交流があ ったため、幼い頃より欧米の文化に慣れ親しんで育った ${ }^{11)}$ 。旅順の 小学校、中学校、東京の旧制第一高等学校加ら東京帝国大学建築学 科に入学、1922 年に卒業した。在学中よりフランク・ロイド・ライ 卜を敬い、帝国ホテルの現場手伝いを経て、1923 年 4 月より信子夫 人とともに渡米、ロサンジェルスおよびウィスコンシン州タリアセ ンにてライトの事務所に勤務しながら、所員たちとの共同生活を経 験した ${ }^{12)}$ 。師であるライトや、友人であるリチャード・ノイトラ、 ルドルフ・シンドラー、ワーナー・モーザーらとの交流を含めた 2 年半のアメリカ生活は、建築家としての土浦の基本的姿勢を培った といえる。1926 年 1 月に帰国すると、御茶ノ水の文化アパートに住 み、大倉土木に勤務する傍ら、個人的にも住宅を設計し、設計競技 に参加した ${ }^{13)}$ 。さらに 1934 年 11 月に大倉土木を辞して、東京の京 橋に土浦亀城建築事務所を設立 ${ }^{14)} 、 1969$ 年に事務所を閉鎖するまで、 商業施設、住宅、病院建築等の分野で設計活動を行った。その間、 1939 年から 1943 までは、中国東北地方の長春（旧新京）に支所を 置き、満州国迎賓館や新京市長公邸などを設計した ${ }^{15)}$ 。戦前の代表 的な作品として、強羅ホテル、野々宮アパート、徳田邸（トクダビ ル）などのコンクリートによるモダニズム建築や、自邸 2 件 ${ }^{16)}$ を含 
【表1】土浦重城住宅リスト(戦前)

\begin{tabular}{|c|c|c|c|c|c|c|c|c|c|c|c|c|c|c|c|c|}
\hline \multirow[t]{2}{*}{ No. } & \multirow[t]{2}{*}{ 作品番白 } & \multirow[t]{2}{*}{ 建物名称 } & \multirow{2}{*}{ 建笑年 } & \multicolumn{3}{|c|}{\begin{tabular}{|l|} 
資料 \\
\end{tabular}} & \multirow{2}{*}{ 所在地 } & \multirow[t]{2}{*}{ 構造 } & \multicolumn{2}{|l|}{ 外観 } & 起居粎式 & \multicolumn{3}{|c|}{ 和室 } & \multirow{2}{*}{ 教地 } & \multirow[t]{2}{*}{ 延林面積 } \\
\hline & & & & 图面 & & 写真 & & & \begin{tabular}{|l|l|} 
5 & 国 \\
\end{tabular} & 湦和 & \begin{tabular}{|l|l|} 
1混: \\
\end{tabular} & 和室数 & 和室位置·用途 & 混在型 & & \\
\hline 1 & - & 山拲㽎 & $1926 \mathrm{C}$ & 0 & E & - & 府下駒場 & 木1 & E & & 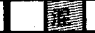 & & 1䧏居間 & 公居 & & \\
\hline 2 & $=$ & 山本期 & 1927 & 은 & - & $\mathrm{o}$ & 神田楼河台 & $\exists 3$ & in & & 聇 & & 1階夫人室、客室、3階客間、次間 & 私 & & \\
\hline 3 & 3002 & 伊藤期 & & - & $\mathrm{O}$ & 0 & & 木2 & 1 & & II & & 2階子供室 & 私 & & \\
\hline 4 & -1 & 谷井的 & 1930 & $\mathrm{O}$ & - & $\mathrm{O}$ & 世田谷代田 & 木2 & 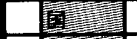 & & 瞋 & & 階居間、2階客間 & 公居 & 177.48 & 47.85 \\
\hline 5 & $\overline{-}$ & 大䐦期 & & $E$ & - & $\mathrm{O}$ & 田無南原 & 木2 & 16) & & In & & - & - & 301.8 & 42.56 \\
\hline 6 & 3101 & 德田的 & 1931 C & $\mathrm{O}$ & $\mathrm{O}$ & 0 & 京橋 & 26 & 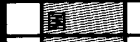 & & 寉 & & - & - & & 42.58 \\
\hline 7 & 3102 & 俵的 & 1931 & $\mathrm{o}$ & 0 & 0 & 小石川第籠町 & 木乾2 & Tintet & & 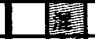 & & 2 階客間 & 私 & & 49 \\
\hline 8 & 3104 & 平林邱 & 1931 & o & E & $\mathrm{O}$ & 牛这納戸町（市公 & 木乾2 & (10) & & 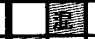 & 既存 & & $E$ & 301.65 & \\
\hline 9 & 3105 & 土浦邸(1) & 1931 & 0 & 0 & $\mathrm{O}$ & 下大崎町 & 木乾2 & 19) & & 霬 & & $f_{-}$ & - & & 33.25 \\
\hline 10 & 3203 & 植村的 & & - & $\mathrm{O}$ & 0 & 世田谷砧村 & 木2 & & 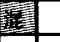 & 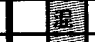 & & 6階老人室、夫人室、2階客室、子供 & 私 & & 141.15 \\
\hline 11 & 3206 & 吉野阰 & & $\mathrm{O}$ & $\mathrm{O}$ & $\mathrm{O}$ & 澉谷神山 & 木2 & 電垔 & & 箠恝 & & 1階主人用 & 私 & 264.21 & 81.67 \\
\hline 12 & 3208 & 安川邸 & 1935 & - & $\mathrm{O}$ & E & & $\beth 2$ & & & 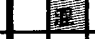 & & 12 階座数 & 私 & & \\
\hline 13 & 3209 & 遠藤期 & & $\mathrm{O}$ & $E$ & E & & & & & & & & E & & \\
\hline 14 & 3211 & 三浦阰 & 1937 & - & $\mathrm{O}$ & $\mathrm{O}$ & 大森田園調布 & 木2 & & & 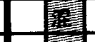 & & 2階座教、曹室 & 私 & 121.14 & 42.41 \\
\hline 15 & 3301 & 伊藤䀦 & 1933 & 0 & 0 & $\mathrm{O}$ & 芝三田(二の畨) & 22 & 14014 & & 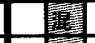 & 既存 +3 & 32階座数他 & 私 & & \\
\hline 16 & 3303 & 石井㿟 & 1933 & $\mathrm{O}$ & E & $\mathrm{O}$ & 仁川(兵庫) & 木2 & 101 & & 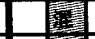 & & 1 (名称なし) & 私 & 118.95 & 46.3 \\
\hline 17 & 3304 & 富永䵝 & 1933 & $\mathrm{O}$ & $\mathrm{O}$ & $\mathrm{O}$ & 目黒下目黒 & 木2 & 10. & & 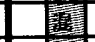 & & 2階座数 & 私 & 580.28 & 55.5 \\
\hline 18 & 3305 & 立能 & 1933 & $\mathrm{o}$ & E & $E$ & 品川五反田 & 木2 & (增䇥) & & 1 & & \begin{tabular}{|l|l|}
4 & 1 皆安室、客間 \\
\end{tabular} & 私 & 316.49 & 120.25 \\
\hline 19 & 3306 & 若林邱 & 1933 & $\mathrm{O}$ & $E$ & - & & $\exists 2$ & 1010 & & 潼集 & 既存 +1 & 2階8鲁 & 私 & & 113.3 \\
\hline 20 & 3307 & 米原毁 & 1933 & $\mathrm{O}$ & E & E & 鳥取 & 木2 & & 籍 & & & 7 全空和室 & 私 & & \\
\hline 21 & 3313 & 野口烸 & 1933 & $\mathrm{O}$ & E & E & 代々木 & & & & & 不明 & & E & & \\
\hline 22 & 3314 & 山本博的 & 1933 & $\mathrm{O}$ & 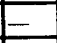 & $\mathrm{O}$ & 豐島目白㽗 & 木2 & 1010 & & 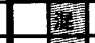 & & 4 & 私 & 831 & 218 \\
\hline 23 & 3315 & 沢野的 & 1933 & $\mathrm{O}$ & $\mathrm{O}$ & $\mathrm{O}$ & 兵庫県住吉村 & $\exists 2$ & & & 1 & & 1 1 陼8畳(食連4引) & 公連 & 391.28 & 105.64 \\
\hline 24 & - & 竹内邸 & 1933 & E & - & 0 & 上大崎長者丸 & 木2 & (10) & & 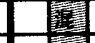 & 既存 & & F- & 816.21 & \\
\hline 25 & 3405 & 高橋期 & & $\mathrm{O}$ & $\mathrm{O}$ & 0 & 赤坂一ツ木 & 木2 & 101 & & $\square$ & & 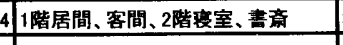 & 私 & 300 & 156.4 \\
\hline 26 & 3407 & 今村邸 & 1934 & $\mathrm{O}$ & 0 & $\mathrm{O}$ & 杉並成宗 & 木乾2 & 10 & & 薄 & & 0 & - & 600 & 56.5 \\
\hline 27 & 3412 & 高島邱 & 1938 & $\mathrm{O}$ & 0 & 0 & 品川北品川 & 木乾2 & 垌 & & 1 & & 2 2陵萝室·客間 & 私 & 120 & 68.8 \\
\hline 28 & 3413 & 3 山森期 & 1934 & $\mathrm{O}$ & E & - & 六甲 & 木2 & & 蛲 & 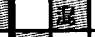 & & 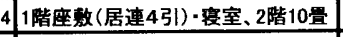 & 公連 & & 81.35 \\
\hline 29 & 3502 & 長谷川邸 & 1935 & $\mathrm{O}$ & $\mathrm{O}$ & $\mathrm{O}$ & 上大崎長者丸 & 木2 & (1) & & 倩 & & $0-$ & - & 70 & 44.75 \\
\hline 30 & 3503 & 中野郎 & 1931 & $\mathrm{O}$ & - & $\mathrm{O}$ & & 木1 & 1010 & & & & & E & & \\
\hline 31 & 3505 & 三島邸 & 1934 & $\mathrm{O}$ & $\mathrm{O}$ & $\mathrm{O}$ & 港谷千䭾ヶ谷 & 木2 & 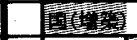 & & 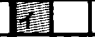 & & 0 & - & 191.8 & $61.82(49.19$ \\
\hline 32 & 3507 & 名會䵝 & 1935 & $\mathrm{O}$ & E & - & 名古屋 ' & 木2 & & 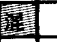 & 笙 & & 2 1階子供室、2階10輜 & 私 & & \\
\hline 33 & 3508 & 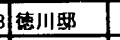 & 1935 & $\mathrm{O}$ & $\mathrm{O}$ & 은 & 港谷猿楽 & 23 & 1900 & & (t) & & 2 22擆座敖 & 私 & 1652.3 & 382.84 \\
\hline 34 & 3509 & 9 北周邱 & 1935 & $\mathrm{O}$ & - & $E$ & & 木2 & & & 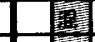 & & \begin{tabular}{|l|l|}
21 & 階8量、2擆客間 \\
\end{tabular} & 私 & & 56.3 \\
\hline 35 & 3510 & 北村邱 & 1935 & $\mathrm{O}$ & $\mathrm{O}$ & E & 井获町 & 木2 & & 輩 & 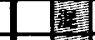 & & 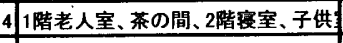 & 私 & 358.34 & 36.66 \\
\hline 36 & 3511 & 杉森邸 & 1935 & $\mathrm{O}$ & 0 & - & 井获町 & 木2 & & 鐡 & 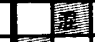 & & 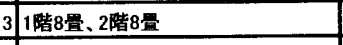 & 私 & & 34.75 \\
\hline 37 & 3512 & 田宮邱 & 1935 & 0 & $\mathrm{O}$ & $\mathrm{O}$ & 豊島長崎南町 & 木乾2 & 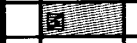 & & 雍 & & 0 & - & 154.38 & 47.2 \\
\hline 38 & 3601 & 鈴木的 & 1936 & $\mathrm{O}$ & E & $\mathrm{O}$ & 三魔村下連雀 & 木2 & 和 & & 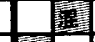 & & 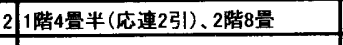 & 公連 & & 53.67 \\
\hline 39 & 3602 & 尚的 & 1936 & $\mathrm{O}$ & $\mathrm{O}$ & $\mathrm{O}$ & 目黒柿の木坂 & 木2 & & 箠 & 墔睢 & & 0 & - & & 79.75 \\
\hline 40 & 3603 & 香川的 & 1935 & $\mathrm{O}$ & - & 0 & 泚谷猿楽 & 木2 & 1 & & 1 & & \begin{tabular}{|l|l|}
3 & 階䒺の間(食連2引)、2階2室 \\
\end{tabular} & 公連 & 209.31 & 60.56 \\
\hline 41 & 3604 & 魚谷的 & 1936 & $\mathrm{O}$ & $\mathrm{O}$ & 0 & 啮谷猿楽 & 木2 & 1 & & 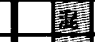 & & 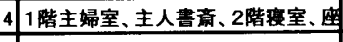 & 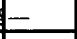 & 541.37 & 118.12 \\
\hline 42 & 3605 & 宮口的 & 1936 & $\mathrm{O}$ & - & $\mathrm{O}$ & 港谷青葉 & 木2 & 丽 & & 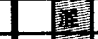 & & 1 1階座﨡 & 私 & 1027 & 76.13 \\
\hline 43 & 3614 & 赤星邸 & 1936 & 0 & 0 & $\mathrm{O}$ & & 木2 & 110 & & 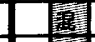 & & 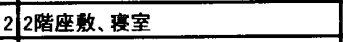 & 私 & & 44 \\
\hline 44 & & 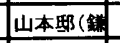 & 1936 & O & - & - & 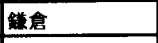 & 木2 & 010 & & 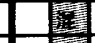 & 既存 & & $E$ & & 增築33.26 \\
\hline 45 & 3703 & 3 竹原的 & 1937 & 0 & $\mathrm{O}$ & $\mathrm{O}$ & 麻布一本松 & 木2 & 170 & & 口霍箦 & & 1 2階8量 & 私 & 135.25 & \begin{tabular}{|l}
75.79 \\
\end{tabular} \\
\hline 46 & 3704 & 岩出邱 & 1937 & $\mathrm{O}$ & $\mathrm{O}$ & $\mathrm{O}$ & 神田駿河台 & 木1 & 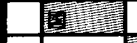 & & It & & $0-$ & $E$ & 148.44 & 56.25 \\
\hline 47 & 3705 & 池尾㿟 & 1938 & $\mathrm{O}$ & $\mathrm{O}$ & $\mathrm{O}$ & 品川五反田 & 木2 & & 霏 & 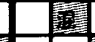 & & 1 2階座敖 & 私 & 199.97 & 76.9 \\
\hline 48 & 3706 & 上野的 & 1936 & $\mathrm{O}$ & $\mathrm{O}$ & $\mathrm{O}$ & & 木1 & & 策 & & 嚄 & 5 座教、客間、要室 & 私 & & 107.24 \\
\hline 49 & 3709 & 遠藤邸 & 1937 & $\mathrm{O}$ & $\mathrm{O}$ & $\mathrm{O}$ & 世田谷 & 木1 & & 琵 & 1 & & 0 & E & 383.77 & 69 \\
\hline 50 & 3712 & 保坂病院 & 1939 & $E$ & 0 & $\mathrm{O}$ & 等地 & 73 & 16) & & 篅 & & 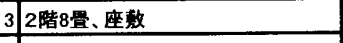 & 私 & & \\
\hline 51 & 3803 & 鈴木(固)的 & & - & $\mathrm{O}$ & $\mathrm{O}$ & 目黑平 & 木2 & & 䀧 & $\square$ & & 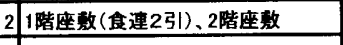 & 公連 & & \\
\hline 52 & 3805 & 土浦的 (2) 1 & 1935,3 & $\mathrm{O}$ & - & $E$ & 上大猗長者丸 & 木乾2 & 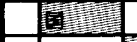 & & 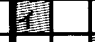 & {$[2]$} & 地陵6骨半、2陵9鲁 & 私 & & 46.1 \\
\hline 53 & 3903 & 吉野別阰 & 1936 & $\mathrm{O}$ & o & - & 秋谷 & 木2 & & 䠐 & & 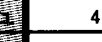 & 4 10量、8量、6黄、4睤半 & - & & \\
\hline 54 & 3909 & 原信太郎阰 & & $E$ & $\mathrm{O}$ & $\mathrm{O}$ & & 木1 & & 鴊 & & 琵 & 1 座敖 & - & & \\
\hline 55 & 4018 & 过秋山郳 & & $E$ & $\mathrm{O}$ & $E$ & & 木2 & & & 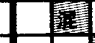 & & 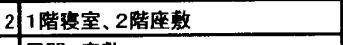 & 私 & & \\
\hline 56 & 4202 & 荒井的 & & - & $\mathrm{O}$ & - & & 木1 & & & & 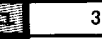 & 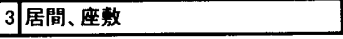 & E- & & \\
\hline
\end{tabular}

作品番号 : 図面、写真、KAMEKI' $S$ 設計 PLAN に付されている番号

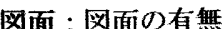

所在地：図面や雑誌に記載された地名

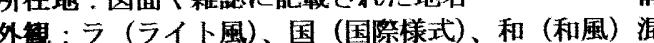

起居梯式：1 (椅子坐式)、工 (床坐式)、混 (混在型)

造 : コ ( RC 造)、木 (木造)、乾 (乾式構造) 数字（階数）

和室位膡・用途：(食連 4 引）は、その和室が食堂に連綍しており、その間に 4 枚の引き戸があることを示す。

混在の型 : 起居様式の混在型の分類 私 (和私室混在型)、公居 (和公室混在型 (居間))、公連 (和公室混在型 (連続))

敷地 - 延床面櫴 : 単位 (坪)

*存在しないものは (一)、不明なものは空欄とした。 
む木造乾式構造の住宅が挙げられる。これらの作品のなかで、現存 する土浦邸（2）すなわち「土浦家住宅」は東京都指定有形文化財 (建 造物）に指定されており、日本におけるモダニズム住宅の代表例と 評価されている ${ }^{17)}$ 。なお、士浦はこの自邸に 1935 年の竣工時から 1996 年に亡くなるまで居住した。

\section{3. 戦前期の住宅の概要}

寄贈された建築図面および建築写真 ${ }^{18)}$ 、さらに「KAMEKI' $S$ 設計 PLAN」 ${ }^{19)}$ の平面図から、土浦亀城あるいは土浦亀城建築事務所の戦 前の日本国内の住宅作品として 56 件 ${ }^{20)}$ 【表 1】にあげた。

鹵国後の最初の 2 件の住宅、1926 年の山縣邸 (No. 1)（【表 1】の No.を（）内に記す。以下同様）と、1929 年の山本邸（No.2）は、 大倉土木株式会社建築部として土浦が設計を担当したもので、フラ ンク・ロイド・ライトのデザイン・ボキャブラリーを多用した住宅 である。しかし 1930 年以降は、「白い都市型モダニズム」とよばれ る国際様式の外観をもつ住宅が多く建てられるようになった。その 転換の理由は、当時のフォイエルシュタインとの交流が指摘されて いる ${ }^{21)}$ が、その他にアメリカ時代の友人であるリチャード・ノイト ラやワーナー・モーザーから得たヨーロッパのモダニズムの知識と、 その合理性・機能性への同調があげられる ${ }^{22)}$ 。土浦は日本の住宅改 善のために、安価で合理的な工法として木造乾式工法を開発、1931 年から 1935 年までに 7 件の住宅を建てた。この木造乾式工法の住宅 を含め、平坦な大壁の壁面と陸屋根をもつ国際様式の住宅が、1937 年頃まで多く建てられた。構造が判明している住宅 53 件のうち、木 造は 46 件、コンクリート造は 7 件というように、土浦の住宅の多く は木造であった。

戦前期の住宅の約半数が 1934 年 12 月に事務所を設立する以前に 建てられており、大倉土木に勤務する傍ら、個人的にも活発な設計 活動を行っていたことがわかる。谷井邸 (No. 4)、大脇邸 (No. 5)、土 浦邸 (1) (No. 9) ${ }^{23)}$ 、土浦邸 (2) (No. 52) は、信子夫人との共同設計 ${ }^{24)}$ で、都市の若い知識階層を施主とした住宅である。一方、植村邸 (No. 10) は、大倉土木の設計で担当が土浦であり、山本博邸 (No. 22)、 池尾邸 (No. 47)などの大規模な住宅は、大倉土木を介して設計依頼さ れた ${ }^{25)}$ 。事務所設立後に、住宅の規模と外観が多様化する傾向が見 られるが、国家総動員法が施行された 1938 年以降、住宅数は減少す る。コンクリート造の保坂医院以外に国際様式の外観はなくなり、 勾配屋根の木造平屋が増加した。

\section{4. 外钼と起居様式}

\section{4-1 外镭}

外観が不明な 8 件を除く 48 件の外観をその特徴から、A. ライト 風 [ラ]：ライトのデザイン・ボキャブラリーを用いた外観意匠を もつもの B. 国際様式[国] : 外壁は平坦な大壁、屋根は陸屋根で白 色系の箱型であるもの c. 和風 [和 $：$ 外壁は真壁で、屋根は勾配屋 根であるもの D. 混在型[混]：外壁は平坦な大壁、屋根は勾配屋根 であるもの、に分類して検討する ${ }^{26)}$ 。

外锤が国際様式であるものは、32 件 ${ }^{27)}$ と多数をしめ、1930 年か ら 37 年までに集中している。ライト風は 2 件、和風は 3 件、混在型 は 11 件であった。混在型は、1934 年以前は植村邸 ${ }^{28)}$ だけであるが、 1935 年以後は 10 件に増加した。外観について概略化すると、ライ 卜風 $\rightarrow$ 国際様式 $\rightarrow$ 混在型というように変化した。【図 1 】浦は、

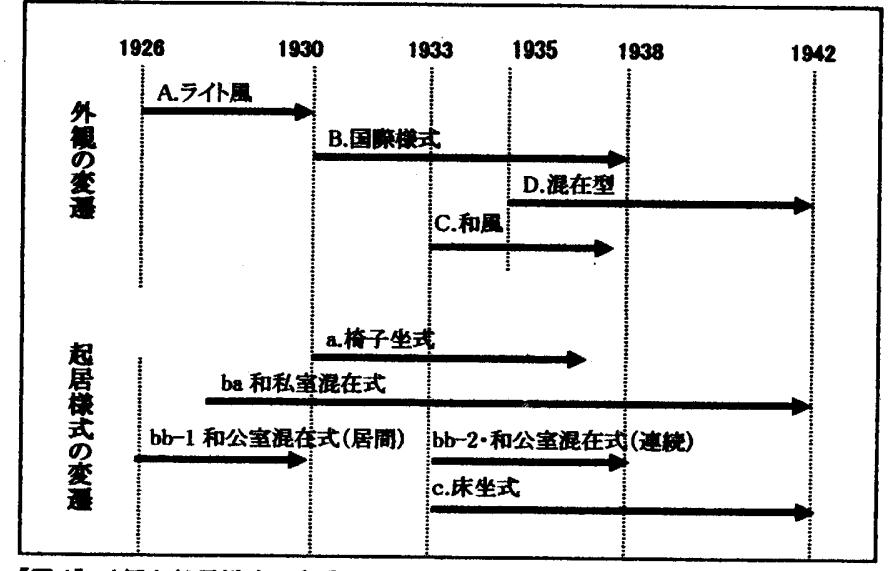

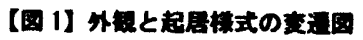

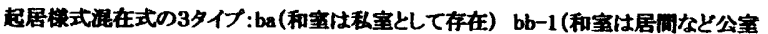

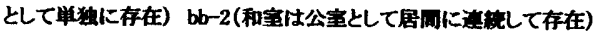

「在来の様式から新しいものに踏み出そらとするときには、まず在 来の様式を打ち壊す」必要があり、そのために「やはり真四角なも のを建てていくということをやったわけで、真四角なものが最終的 なものだと思ってやったわけじやない」 ${ }^{29)}$ と述心゙ており、国際様式 の外観が住宅改善の手段であったことを示唆している。土浦にとっ て「国際様式」の外観は、住宅改善にもっとも効果的な合理的な形 態を表象するものであった。だからこそ木造住宅における陸屋根の 難しさを了解した上で採用した ${ }^{30}$ のだが、最初に国際様式の外観を 用いた 5 年後の 1935 年頃から、より現実的な勾配屋根（特に切妻屋 根）を採用するようになった。この「混在型」は、白い平坦な壁面 と切妻屋根をもつものが大半を占めるが、なかには部分的に羽目板 を貼った外壁や、複雑な屋根形態をもつものもある。これは、住宅 改善に有効な「国際様式」の外観が、すでに新しいものではなくな ったこと、さらに事務所所員の増加により、作品が多様化したこと がその理由であろら。なお、和風の外観は 1933 年以降 3 件見られる が、土浦の作品としては異色である。

\section{4-2. 起居様式}

すでに指摘されているように土浦の住宅の特徵は居間・食堂を中 心とする平面計画にある ${ }^{31)}$ 。南面する居閒とそれに連続する食堂を もつ住宅は 43 件あり、それらは椅子坐式を基本としている。起居様 式加 a. 椅子坐式 [1] : 和室 ${ }^{32)}$ のない住宅、b. 混在式 [混]：椅 子坐式と床坐式 (和室) が混在する住宅、c.床坐式 [ユ] : 和室が 中心の住宅に分類して検討する。なお、増築として建設された平林

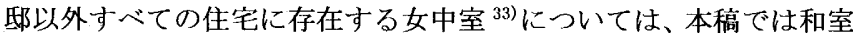
数に数えていない。当時女中室を盢敷とするのは西洋館においても 一般的であった ${ }^{34)}$

a. 椅子坐式 [イ〕：和室のない住宅

和室のない椅子坐式の住宅は 11 件である。2 件の自邸を含め、 その施主の多くは欧米での生活経験者であった。大脇邸の場合、お 茶の水の文化アパート時代に土浦と知り合った施主が椅子坐式の生 活を希望したという ${ }^{35)}$ 。徳田邸は、アメリカで学んだ歯科医師が施

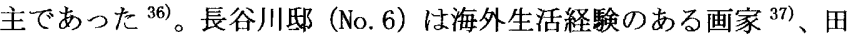
宮邸(No. 37) は留学経験のある理学博士、遠藤邸(No. 49)【図 9】は、 八ワイから戻った事業家が施主であった ${ }^{38)}$ 。土浦邸 (2)（No. 52）【図 2】の場合、1935 年の新築時においては椅子坐式のみであったが、 

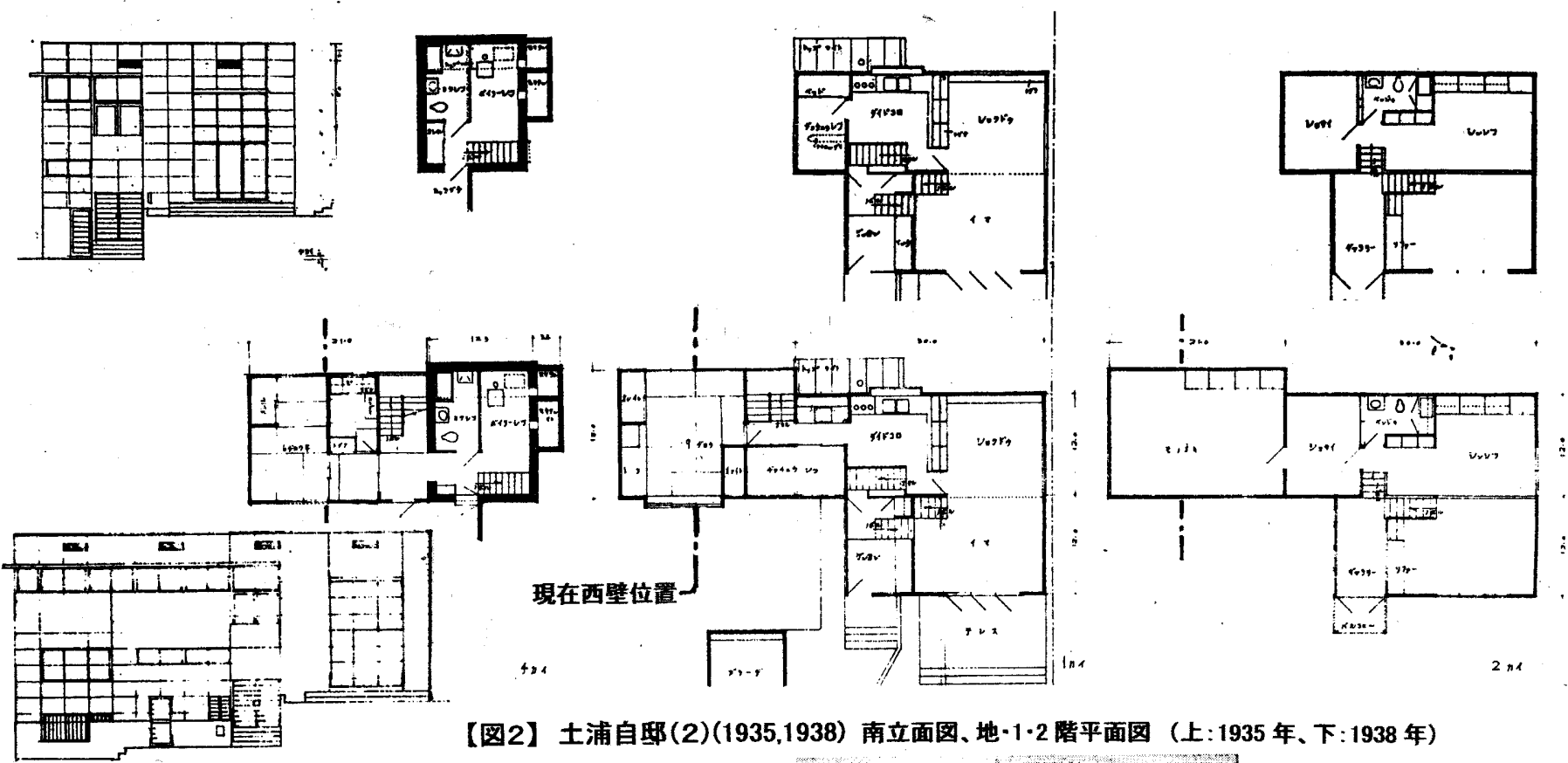

1938 年に土浦の母の部屋として 1 階に 9 畳、母の使用人のための部 屋として地階に 6 畳半の和室を増築した。しかし増築部の大半は、 母の死後 1958 年頃に取り壊されて現在に至っており ${ }^{39)}$ 、土浦自身 は和室を全く使用しなかった。

b. 混在式〔混〕：椅子坐式と床坐式が混在する住宅

椅子坐式と床坐式が混在する住宅は、既存建物に和室がある 4 件 40)を含む3 37 件であった ${ }^{41)}$ 。混在式平面計画の大半は、椅子坐式の 居間・食堂を中心としており、和室は客間、老人室、寝室、座敷な どの個室（私室）として存在するものと、居間・食堂など公的な部 屋（公室） ${ }^{42)}$ として存在するものの二つのタイプがある。前者を和 私室混在式 ba. 後者を和公室混在式 bb. に分類する。

ba. 和私室混在式 : 椅子坐式中心で個室としての和室がある住宅

書斎、客間、座敷、老人室、主婦室などの私的な和室の多くは、 2 階に位置している。それらの和室の出入り口には開き戸が多く見 られ、和室も個室の一つとして扱われていることが平面図から読み 取れる。数少ない和室の写真や図面から内装を調べると、赤星邸 (No. 43)【図6】のように大壁、平天井のものと、山本博邸 (No. 22)、 角谷邸 (No. 41)、池尾邸（No. 47）【図 7 1、鈴木邸（No.51）のよう に、真壁・竿縁天井 ${ }^{43)}$ のものが存在した。格式を表現する床・棚を 備えた正式な和室の場合は、伝統的な真壁・竿縁天井を用いており、 土浦は二つのタイプの和室を使い分けていた。

bb. 和公室混在式 : 椅子坐式中心で公的な和室がある住宅

初期の山縣邸（No. 1)【図 3 】と谷井邸（No. 4）【図 5】では、生 活の中心となる位置に和室が置かれている。まず山縣邸の居間は、7 畳半の和室である。他の部屋が洋閒であるにもかかわらず、居間の み和室としているのは、床坐式の食事と団樂が施主の家族に不可欠 だったためと思われる。また谷井邸では、1 階食堂と子供室の間に 和室がある。「全部が椅子式であれば、1 階の 3 室は引き戸あるいは 折り畳戸で連続され、必要に応じて、あるいは大きな 1 室として、 あるいは 2 室、3 室として使用する事ができて、はるかにフレキシ ブルな間取りとなります。2 階も同様」と土浦は記述しており ${ }^{44)}$ 、 椅子坐式の徹底を意図したが果たせなかったことがわかる。以上の
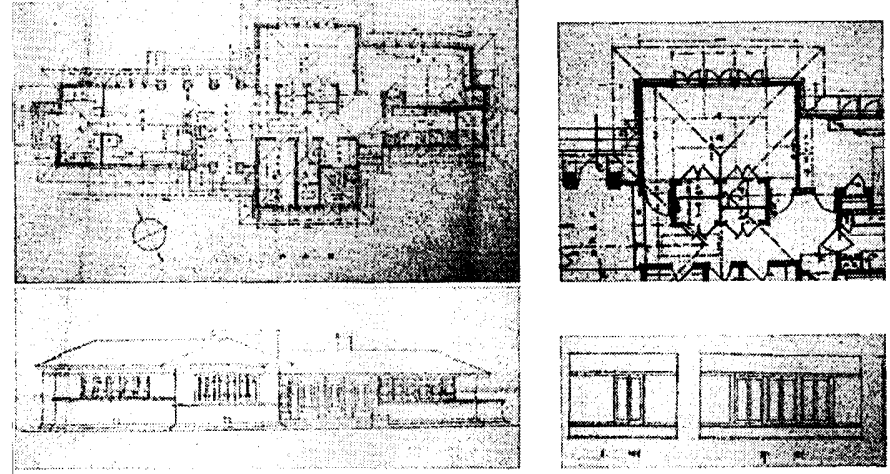

【图3】山整昍(No.1) 南立面图、平面図、居間平面图-展閒园(東面、南面)

2 例は、生活の中心となる居間が和室という床坐式の起居様式から 脱することのできない時代背景を反映しており、この 2 例以外には 存在しない。1933 年以降は、椅子座の居間・食堂に隣接・連続する 和室が出現し、沢野邸(No. 23)のように 2 連あるいは 4 連の引戸(燠) によって居間や食堂と連続可能な和室が 5 件存在した ${ }^{45)}$ 。前者を 「和公室混在式 (居間)」(bb-1)、後者を「和公室混在式（連続）」 (bb-2) と名づけて分類寸ると、前者は 1930 年以前、後者は 1933 年 以降にみられた。【図 1】

c.床坐式 [ㄱ] : 和室が中心の住宅

全室和室ないし和室を主とした平面をもつものは 5 件である。 1933 年の米原邸（No. 20）【図 8】を除く他の 4 件は1937 年以降に建 設されており、第二次世界大戦に関連した住宅不足と経済状況の悪 化を反映している ${ }^{46)}$ 。

以上の起居様式の変遷を概略化すると、「混在型」は全般にわた ってみられ、椅子坐式は 1930 年から 1937 年に、床坐式は 1933 年以 降にみられた。図 1】

\section{4-3. 外臨と起居様式の関係}

外観と起居様式の関係を数量的に図示するために、外観（国際様 式一混在型-和風）を $\mathrm{x}$ 軸に、起居様式（床坐式-混在式-椅子坐式） を $\mathrm{y}$ 軸にとり ${ }^{47)} 、 \mathrm{~B}-\mathrm{a}, \mathrm{B}-\mathrm{b}, \mathrm{B}-\mathrm{c}, \mathrm{D}-\mathrm{a}, \mathrm{D}-\mathrm{b}, \mathrm{D}-\mathrm{c}, \mathrm{C}-\mathrm{a}, \mathrm{C}-\mathrm{b}, \mathrm{C}-\mathrm{c}$ という 9 つの欄に, 該当する住宅作品 N0.を記入した。【図 10】外 

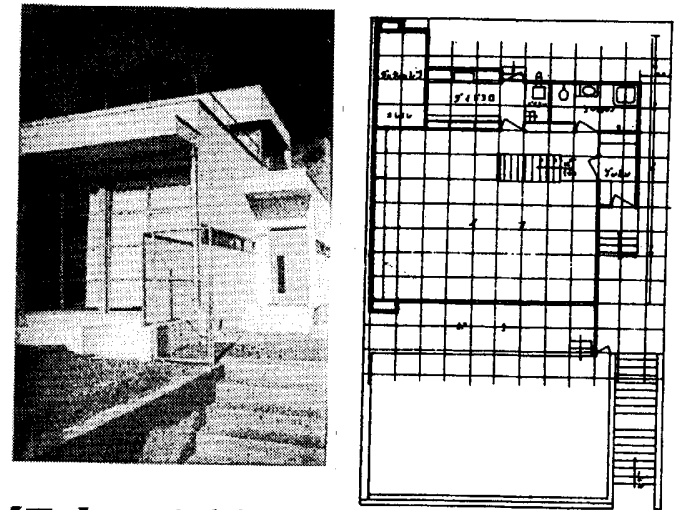

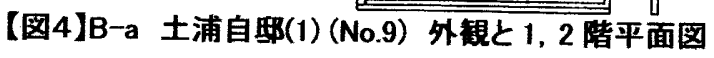
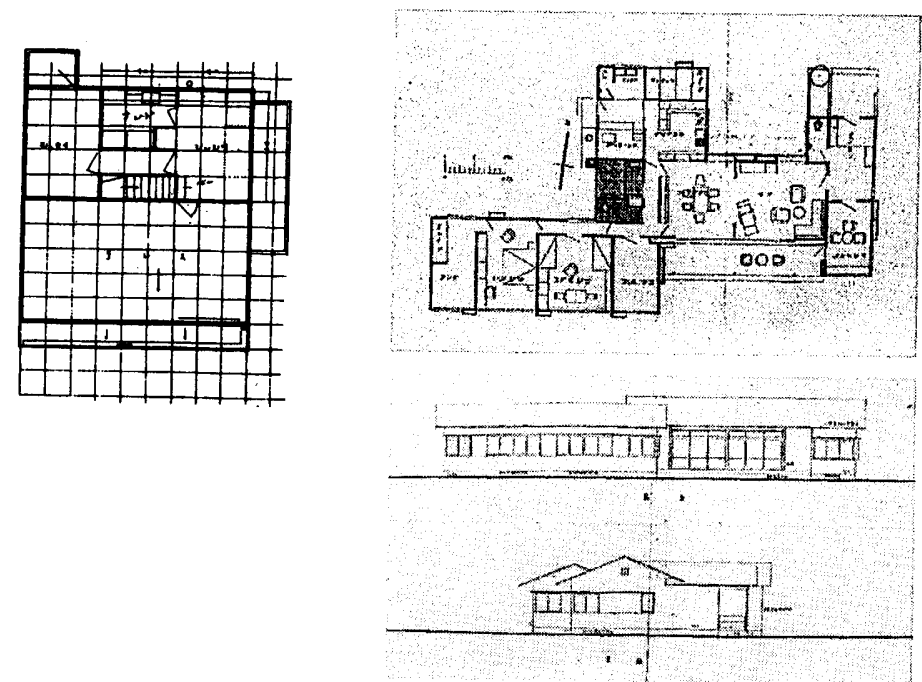

【图 9】D-a 遠藤邱(No.49）南立面图、1 陵平面図

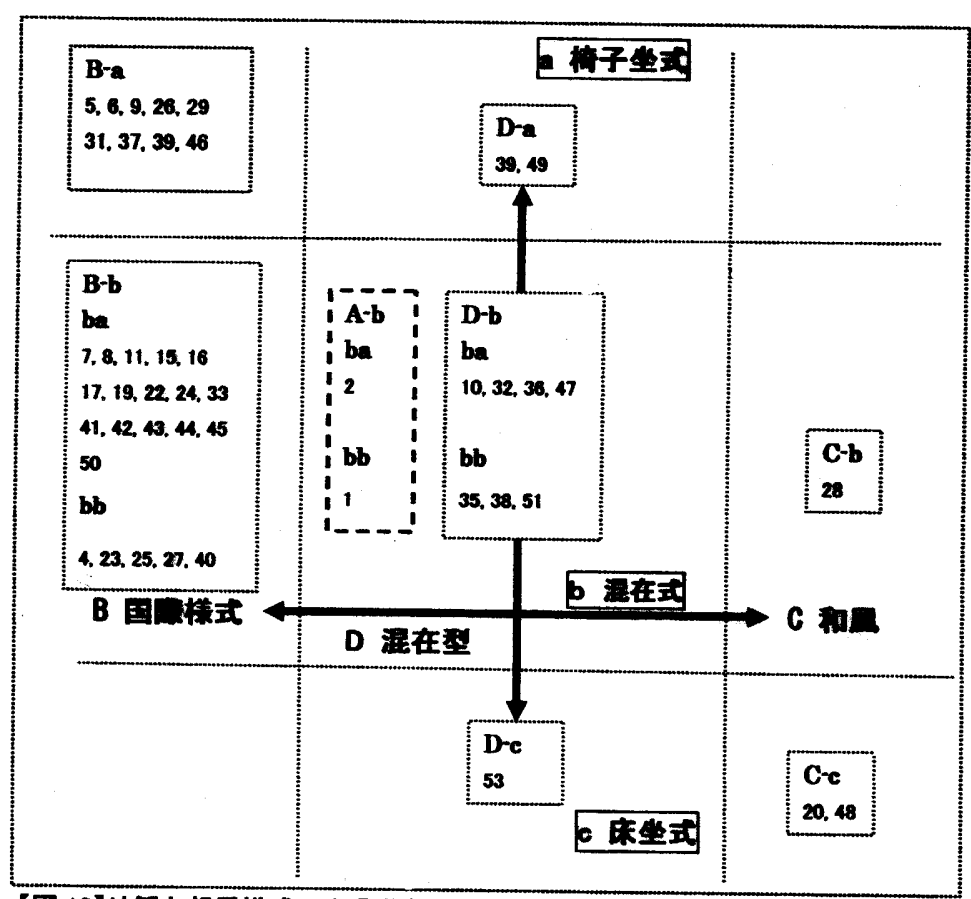

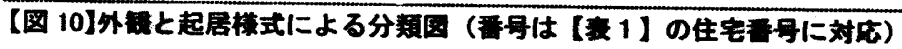

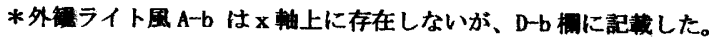

*混在式 b は、ba 私室混在型および bb 公宣混在型に分けて記載した。
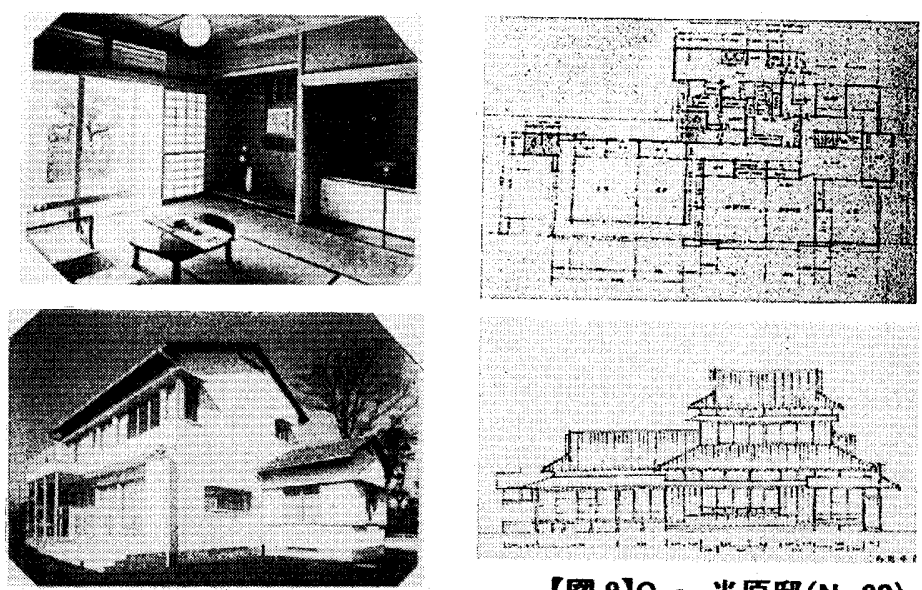

【图 7】D-b 池尾邱 (No.47) 外钼と和室

\section{to}

【图 8】C-c 米原㿟(No.20) 南立面图、1 踏平面图

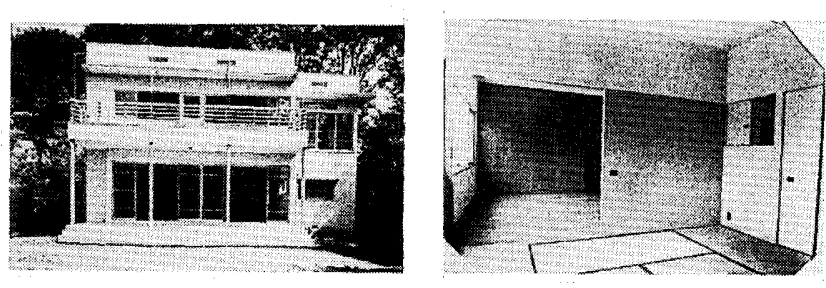

【図 6】B-b 赤星㿟(No.43)外観、和室、1-2 階平面図

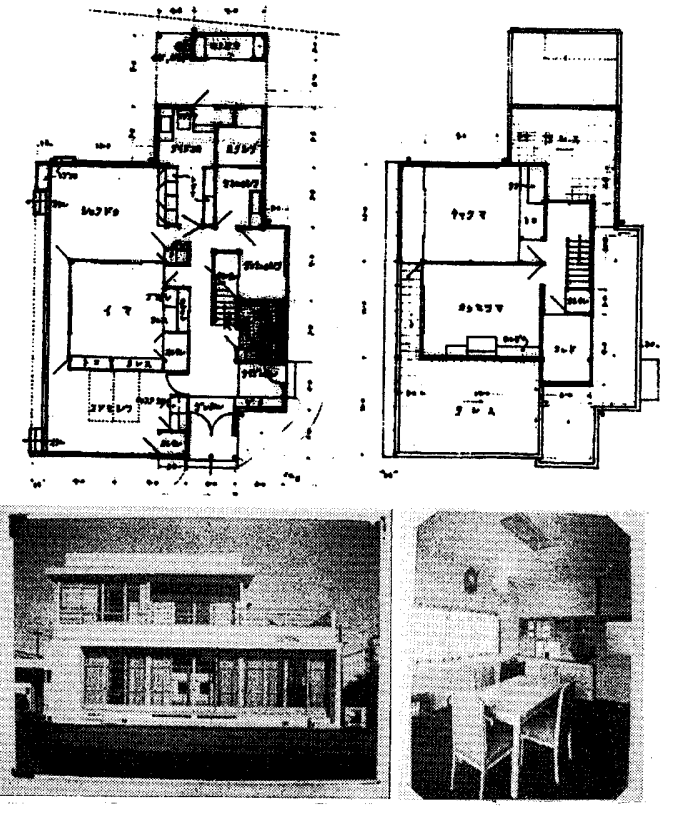

【図5】B-b 谷井邸(No.4)）外観、食堂、1-2擆平面图
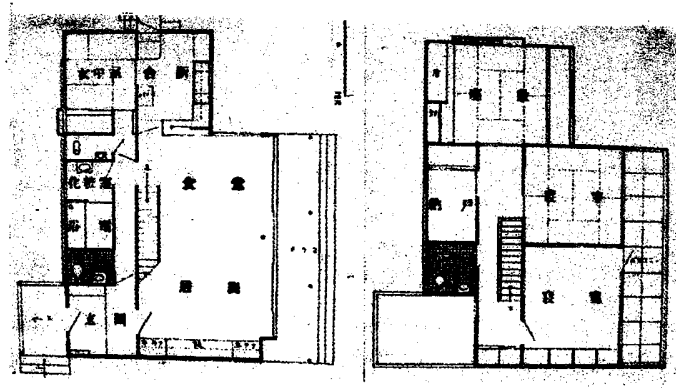
観が国際様式の住宅において、椅子坐式の B-a は 9 件、起居様式が 混在する B-b が 21 件で、 B-c は 0 件であった。外観混在型では、椅 子坐式 D-a が 2 件、混在式 D-b が 1 件、床坐式 D-c が 1 件であった。 外観が和風の住宅では、C-a は 0 件、c-b 1 件、c-c 2 件、外観がラ イト風の住宅では、 $\mathrm{A}-\mathrm{b}$ が 2 件 ${ }^{48)}$ であった。

土浦が、自邸である土浦邸（1）（No.9）【図 4】および土浦邸 (2) (No. 52) の新築時に実現したような、B-a のタイプは、海外生活経 験のある、都市部の若い知識階層のための住宅に限られていた。「半 日を教室で腰掛け、自動車、電車に乗り、スポーツをやる今の学生 には、本式に坐る人が少ないから、近い将来に於いて全く坐らない 時代が来る事を想像し得る。」 ${ }^{49)}$ と、土浦は椅子坐式の生活を念頭に おいて住宅を考えていたが、現実的に和室を必要とする施主が多く、 和室のある B-b のタイプにならざるを得なかった ${ }^{50)}$ 。その場合、国 際様式の外観が損なわれないよう、和室の存在が外観に反映しない 工夫がなされた。谷井邸 (No.4)【図 5】の外観と和室に関して、「居 闍の南側に縁側というか廊下がついているのは、立面に障子等の和 風のものが出てこないようにするためです。」卢と土浦は説明してい る。吉野邸 (No. 11) は 1 階の書斎、富永邸 (No. 17) は 2 階の座敷、 高島邸（No. 27）は 2 階の寝室と客閒、角谷邸（No. 41）は 1 階主婦 室と主人室、赤星邸 (No. 43)【図 6】は2 階座敷と寝室、竹原邸 (No. 45) は音楽室の吹き抜けを見下ろす 2 階の 8 畳間が和室であったが、外 観から見えないように、縁側を設けカーテンをつける、空の高さや 大きさを洋間と合わせるなどの工夫がなされている。また、これら の住宅が雑誌に揭載される際には、国際様式の外観と椅子坐の内部 空閒のみが取り上げられ、あたかも和室がないような印象を与える ことが意図された ${ }^{52)}$

土浦は米国での生活や、文化アパートでの生活経験をふまえ、 「現代人の生活の形式は綮化しつ〉ある。老人や親類を同居させて 居た大家族制度は破壊されつ〉ある。减多に使はない様な客室は要 らない。」 ${ }^{53)}$ と伝統的な住宅の合理化を図っていた。そして住宅建筑 の標準化を第一に考え、「畳が三尺に六尺の大きさで一つのエニッ 卜を成している」伝統的な日本建築を評価していた ${ }^{54)}$ 。それはリチ ヤード・ノイトラが日本の睢や家具の標準寸法を評価したことと同 じ意識であったと思われる ${ }^{55)}$ 。土浦邸(2)に増筑された和室は 9 量 と 6 畳半、山縣邸では 7 冨半と表記があり、伝統的な畳数にこだわ らないのは土浦にとって畳がユニットの単位であったことを示すも のである。また内装について、山縣邸の居間は畳を敷いているもの の、壁面は他の洋間とかわらない意匠となっており、空の形態も外 観を優先している。【図 3】床の間のある伝統的な和室を設けた場合 でさえ、国際様式の外観の統一性を損なうことはなかった。

\section{5. おわりに}

戦前期の住宅の外観と起居様式についてまとめる。外観：「ライ 卜風」 2 件、「国際様式」が 32 件、「和風」が 3 件、「混在型」が 11 件見られた。「国際様式」は、1930 年から 1937 年に集中しており、 1935 年以降「混在型」が増加した。概略化すると、「ライト風」 $\rightarrow$ 「国際様式」 $\rightarrow$ 「混在型」というように変化した。起居様式 : 椅子 坐式 11 件、床坐式 5 件、混合型 37 件であり、居間・食堂を中心と した椅子坐式の平面であっても、多くの住宅において和室が存在し た。椅子坐式は 1930 年から 1937 年に、床坐式は 1933 年以降にみら
れた。外钼と起居様式：土浦が目指し、また雑誌を通して発信した 「国際様式の外観と椅子座の起居様式」という住宅タイプは、9 件 にすぎず、外観は「国際様式」であるが、椅子座と床座を混在させ た住宅が 21 件あった。このように椅子座の徹底は困難であったが、 和室の存在は「国際様式」の外観から判別できないよう空の位置な どが工夫されており、あくまでも外観の純粋性が重視された。

土浦の関心は、日本の住宅の標準化・合理化であり、それを実現 する上で国際様式の外観は有効な手段であった。そして、この国際 様式の住宅は、和室を排除するのではなく、必要に忍じて取り込ん でいたのであり、そこには、畳を「標準化」の単位と捉える基本的 な考え方があった。前述した土浦邸(2)増改築の経緯は、土浦が目指 す「国際様式で椅子坐式」の住宅が、和室を必要とする現実に対応 し、最終的には椅子坐式を貫くという土浦の基本的姿勢を端的に表 しているといえる。土浦が目指したものは、モダニズムの原点であ る標準化された合理的なデザインと住まい方であった。そこでは和 室も眐という床材を使用した個室であり、その考え方は戦後の日本 の住宅に引き継がれた。

【謝辞】本稿をまとめるにあたって資料収集にご協力いただいた中 村常子氏と江戸東京博物館の早川典子氏に感謝いたします。

註

${ }^{1)}$ 西澤泰彦「昭和初期モダニズム一建築家土浦亀城と彼をめぐる人々」『SD』8807、 西澤泰彦「初期モダ二ズ允と建築家土浦龟城」『SD』9607、藤森照信「昭和住宅物 語(1)土浦刍城邸一モダニズムの青春」『住宅特集』88605 等

${ }^{2)}$ 国際建築協会編 昭和 16 年,全 4 巻

3) 土浦亀城の戦前の設計活動に関連した研究として、西澤泰彦「建築家土浦亀城 と昭和初期モダニズム」『SD』8807および「初期モダニズムと建築家土浦龟城』『SD』 9607 があるが、どちらも昭和初期の土浦の住宅をモダニズムの視点から論に゙てお り、最終的にく白い都市型モダニズム〉として完成するとしている。起居様式につ いては論考されていない

1) 2002 年 7 月 25 日に第1回目として、2003 年 3 月 26 日（追加分 2003 年7月 30 日)に第2回目として中村常子氏より寄贈された。

5) 内田青蔵旧本の近代住宅麇島出版会、pp240-241,1996.わが国の近代住宅 の変遷過程を「和館のく洋風化〉」と「西洋館のく和風化＞」の二軸からら見ることを 基本的な視点にしている。

6) 久保加津代「大正デモクラシー期の『婦人之友』誌にみる住生活改善」日本建築 学会計画系論文集第 471 号、pp.155-163、1995.5『婦人之友』に揭載された住宅 をイスザ住宅・ユカザ住宅・混在住宅に分類・考察し、イスザ化を進めようとする専 門家に対して、読者は現実的な混在住宅を望んだと結論づけている。

7) 内田青蔵「椅子坐式生活様式の導入過程に関する一考察一「めめ加屋」の住 宅作品を通して一」住宅総合研究財団研究年報 NO.15、pp.15-28.1988.「あめりか 屋」の住宅は、椅子坐式と床坐式の混合した「和洋折哀住宅であり、椅子坐式の部 屋は大壁、床坐式の部屋は真壁というように、部屋を単位としていたこと、そして大 正末頃から椅子坐式と床坐式の二重生活を当然とする傾向が強かったことが記述 されている。

8) 小川信子「土浦亀城の住宅計画」『SD』1996 年 7 月号 戦前の住宅の平面計画 の特徽として、簡易化」と「公私空間の分離」「食堂と居間のつながり」「食堂と台所 のつながり」が指摘されている。また事績に関するものとして、拙稿「性建築家と しての土浦信子一亀城との協力関係について」日本建築学会大会学街講演梗概 集 2001.9 および「土浦龟城·信子夫妻のア抜力滞在一異文化交流の視点から」日 本建築学会大会学術講演梗概集 2000.9 がある。

${ }^{99}$ 日本建築学会大会学術講演梗概集 2004.9

10) 土浦市松 $(1868$ 1926) 東京帝国大学予備軍卒業。

11) 1989 年 10 月 6 日の土浦亀城氏一の聞き取りによる。

12) 小川信子・田中厚子『ビッグ・リトル・ブ ライトの弟子・女性建築家土浦信子』゙ メ出版、pp.50-103,2000. 1989 年秋に筆者が数回にわたって行った聞き取りをま とめたものである。

13) 西澤泰彦「初期モダニズムと建築家土浦亀城』『SD』1996.07 pp.17-18。東京地 下鉄道株式会社地下鉄ビルヂング設計競技。

14) 1935 年当時の所員圭浦稲城、今井親賢、郡菊夫、松村正恒、河野通祐であ る。1938 年当時は上記に加えて、森田良夫、森田茂介、後に田中正義、笹原貞彦、 村田政真が加わった。河野通祐『虾蟖のつぶやき』大龍堂書店 p.34,p.53, 1997. 
15) 14) 前掲書 p.55. および西㵏泰彦『海を渡った日本人建築家』彰国社. p179, 1996.12

16) 土浦邸(1)(No.9) 拈よ゙土浦邸(2)(No.52)をさす。

17) 平成 7 年 3 月 27 日に指定された。「室内の明るい立体的な組多立ては、モダニ ズム建築の特徵を遺憾なく発揮している。」大正期の田園に建つ潇酒な洋風住宅 から、昭和期の都市型小住宅へ転換していく住宅史の流れを知る上で、久かすこと のできない最も代表的な住宅である。」とプレートに記載されている。

18）奇贈された写真は主に建築作品の外観と室内、そして図面を写したものである。 ファイルに「新建築写」、「アトリエ堀野」「現代建築加藤写真館」等の名称がみられ、 『新建築』、『国際建築』、現代建築』人揭載された写真が含まれる。

19)「KAMEKI’s 設計 PLANJと表書きされた緑色のアルバムに、1930 年から 1942 年までの 45 件の作品の平面図が貼りこまれており、らち住宅・住宅部を含む建物は 35 件である。中村常子氏所蔵。

20) 江戸東京博物館に寄贈された図面と「KAMEKI’s 設計 PLAN」に存在するす心゙ ての独立住宅をさす。ただし、徳田菊科医院(徳田邸、トクダビル)と保坂病院は医 院との併用住宅であるが検討の対象とした。またフアイルのみが存在し、資料のな い吉出邸 (1931)、岩出邸 (1933)、大宮の山本邸(1934) は省いた。土浦自邸(2)は 1935 年の竣工であるが、「KAMEKI’S 設計 PLAN」の作品番号 3805 に従って 1938 年に配した。

21) 藤森照信「土浦亀城邸 モダニズムの青春」『住宅特集』ipp125-126, 1986.05

22) 12)前掲書。pp84-85.

23) アルバム「KAMEKI’ $\mathrm{s}$ 設計 PLAN」では、この自邸と同じ平面図が「3105 岸本邸」 と表記されている。おそらく売却後の居住者名と思われ、本稿では作品番号 3105 を採用し、土浦邸(1)と表記した。

24) 谷井䄮図面の設計者としての署名は、「N. Tsuchiura」、大脇邸と土浦邸(1)では、 「ツチウラカ对・ブ」と連名になっており、信子の設計への関与が認められる。

25) 中嶋いに「土浦刍城」日本女子大学家政学部住居学科昭和五十五年度卒業

論文。戦前期の住宅に関寸る土浦のインタビューが記載される。山本博邸p 175 , 池尾邸p299

26)この分類は本論における分類であり、一般的な住宅の外観分類を考慮したもの ではない。

27) [国]には和風の既存建物に連結して国際様式の住宅を増築したものが含まれ る。

28)「日本風の屋根をもつ洋風住宅」であり、玄関の屋根等のでザインは自分の案で はないことが明記されている。『新建築』1933.08

29)「対談 土浦龟城・磯畸新 1930 年前後」都市住宅』1972.12

30)「屋根は陸屋根にして、テレスとが運動場に使用したいのであるが、木造の場合

には、雨、雪の為に構造と施工方法に適当なる考慮を払わないと不結果に終る事

がある」と記述されている。「新住宅建築の問題」『国際建築』1931.03

31)「住宅の平面は、いずれも居間と食堂が一体となり、できる限り広い面積が確保さ

れ、しかも住宅の中心に置かれている。」13)前掲書 p18.

32) 本稿では、平面図において瞢の表記により胃数が判明する部屋を和室とし、 その他の内装は問題としない。

33) その多くが 3 畳あるいは4畳半であるが、6畳や8畳の例もある。

34) 7)前掲書。p 20 .

35) 25) 前掲書 p.85.

36) 徳田邸は6階建てビルの4,5 階が住宅部分であった。施主の德田鐵三は大正 時代に渡米、ネブラスカ州オマハ市の大学と二ューヨークの大学院で菌科医学を学 び、ヨーロッパ各国の歯科医学を視察しながら、1928 年に帰国したという。植田実 『集合住宅物語』みすずず書房 p. 81,2004

37)施主の長谷川三郎(1906-1957)について土浦は「施主は長谷川三郎といら画

家をしていた人で、ア归力で美術の教授をしたり夫人がア缽力人だったりしたので、 洋式の生活でした。」と語った。25)前揭書p235.

38) 25)前揭書 p218 p310.

39）中村常子氏のご教示による。

40) 平林邸、立邸、竹内邸、三島邸は、和風住宅に繫げて増築され、新築部には和 室がない。

41) 增築の既存部の和室は部屋数に入れず[既存]と示し、新築部のみ和室数を

【表 1】に示した。

42)ここで「公室」とよぶ部屋は、居間や食堂のように家族が集まる部屋を意

味し、対外的に公的な応接間などを指寸ものではない。

${ }^{43}$ 山本邸、角谷邸、宮口邸、池尾邸、鈴木邸俚、真壁·竿縁天井、高橋邸は大壁・

平天井で、赤星邸には両者が見られた。山本的には床の間、違い棚、付書院があ

り、池尾邱と鈴木邸には床の間と付書院がある。

44) 土浦亀城「谷井邸に関して」『新建築』1931.3

45) 井上祐一「遠藤新設計による大正・昭和初期の住宅平面から力た生活空間の変

容について」『日本における大正・昭和前期の住宅にみるフランク・ロイド・ライトの影

響に関する研究』(学位論文、私家版, p.12,2004.では、居間、食堂および座僌の)

関係が「隣室関係」床の段差」建具」の 3 点から考察されており、参考とした。
46) 戦時期の住宅不足に対応寸るために、住宅問題委員会が作成した「庶民住宅 の技術的研究」には、生活方式として「居住の形式は主として坐式とす。」と書かれ ている。『建築雑誌』p80.1941.2

${ }^{47)} 5$ ) 前揭書。pp244-245,1996. 日本の近代住宅の変遷過程を論証した「私論一日 本の近代住宅の系譜」の「系譜図2」を参照した。

48）ライト型は $\mathrm{x}$ 軸上に存在しないが、例外として【図 7】に含めた。

49) 31 ) 前揭書。

50) にこららの場合(土浦自㿟 (2)) 完全洋式ですけど、他の住宅でも日本的な旬い は全部消してデザインされたのですか。」と問われ、「そうもいきませんね。家庭によ っては、やはり年寄りの部屋をひとつ日本間にしてほしいといらのがあります。」答 えている。対談「土浦亀城、磯崎新一九三○年前後」『都市住宅』1972.12 p75. 51) 25) 前掲書 p75

52) 戦前の主要な建築専門雑誌である『国際建築』および新建築』に掲載された住 宅は 30 件である。国際様式といら新しい時代の住宅様式を用いた土浦にとって、の 品の雑誌への発表および作品の見せ方は重要だった。発表された住宅の外観は 国際様式が多く、内部の写真で和室を写した角谷邸の1枚を除くすべてが、居間 や食堂など椅子坐式の起居様式を写したものである。

53) 30) 前掍書。

54) 土浦亀城「住宅建築の標淮化」『文化生活』文化普及会発行昭和 2 年 1 月号 pp94-96.「日本住宅梳、今日までの日本人の生活によく合致し、難点の打所のな い立派なもので且つ安価であった。加ふるに藝術味の豊かであつたことも忘れてけ ならない。」とも記されている。

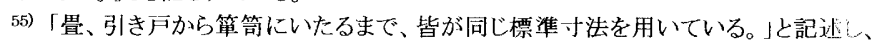
日本の住宅を賞賛している。 Life and Shape, New York: Appleton Century Crofts Publishers, p226, 1962.

(2005年 3 月 10 日原稿受理, 2005 年 8 月 29 日採用決定) 